University of Nebraska - Lincoln

DigitalCommons@University of Nebraska - Lincoln

\title{
Less Waste Corn, More Land in Soybeans, and the Switch to Genetically Modified Crops: Trends with Important Implications for Wildlife Management
}

\author{
Gary L. Krapu \\ USGS Northern Prairie Wildlife Research Center, gkrapu@usgs.gov \\ David A. Brandt \\ USGS Northern Prairie Wildlife Research Center, dbrandt@usgs.gov \\ Robert R. Cox Jr. \\ USGS Northern Prairie Wildlife Research Center
}

Follow this and additional works at: https://digitalcommons.unl.edu/usgsnpwrc

Part of the Other International and Area Studies Commons

Krapu, Gary L.; Brandt, David A.; and Cox, Robert R. Jr., "Less Waste Corn, More Land in Soybeans, and the Switch to Genetically Modified Crops: Trends with Important Implications for Wildlife Management" (2004). USGS Northern Prairie Wildlife Research Center. 65.

https://digitalcommons.unl.edu/usgsnpwrc/65

This Article is brought to you for free and open access by the US Geological Survey at DigitalCommons@University of Nebraska - Lincoln. It has been accepted for inclusion in USGS Northern Prairie Wildlife Research Center by an authorized administrator of DigitalCommons@University of Nebraska - Lincoln. 


\title{
Less waste corn, more land in soybeans, and the switch to genetically modified crops: trends with important implications for wildlife management
}

\author{
Gary L. Krapu, David A. Brandt, and Robert R. Cox, Jr.
}

Abstract American agriculture has provided abundant high-energy foods for migratory and resident wildlife populations since the onset of modern wildlife management. Responding to anecdotal evidence that corn residues are declining in cropland, we remeasured waste corn postharvest in the Central Platte River Valley (CPRV) of Nebraska during 1997 and 1998 to compare with 1978. Post-harvest waste corn averaged $2.6 \%$ and $1.8 \%$ of yield in 1997 and 1998, respectively. After accounting for a 20\% increase in yield, waste corn in 1997 and 1998 was reduced $24 \%$ and $47 \%$ from 1978 . We also evaluated use of soybeans by springstaging sandhill cranes (Grus canadensis) and waterfowl during spring 1998 and 1999. Despite being widely available in the CPRV, soybeans did not occur in esophageal contents of sandhill cranes $(n=174)$, northern pintails (Anas acuta, $n=139)$, greater white-fronted geese (Anser albifrons, $n=198$ ), or lesser snow geese (Chen caerulescens, $n=208$ ) collected with food in their esophagi. Lack of soybean consumption by cranes and waterfowl in Nebraska in early spring builds upon previously published findings, suggesting that soybeans are poorly suited for meeting nutrient needs of wildlife requiring a high-energy diet. Given evidence that high-energy food and numerous populations of seed-eating species found on farmland are declining, and the enormous potential risk to game and nongame wildlife populations if high-energy foods were to become scarce, a comprehensive research effort to study the problem appears warranted. Provisions under the Conservation Security subtitle of The Farm Security and Rural Investment Act of 2002 offer a potential mechanism to encourage producers to manage cropland in ways that would replace part of the high-energy foods that have been lost to increasing efficiency of production agriculture.

Key words corn, cropland, farm bill, fat storage, genetically modified crops, Grus canadensis, harvest efficiency, resident wildlife, sandhill crane, soybeans, waterfowl, weed seeds

Corn and soybeans were harvested on $21 \%$ and $22 \%$, respectively, of the total cropland area of the United States in 2002 (United States Department of Agriculture [USDA] 2002). Production of these crops is centered in the Midwest and Great Plains, with $\geq 90 \%$ of the cropland in Illinois, Iowa, and Indiana and about two-thirds of cropland in Nebraska and Minnesota planted to corn and soybeans (Figure 1). Harvested cropland area in corn has remained relatively stable over the past half-century, soybean area has increased by about $600 \%$, and wheat area has declined by 43\% from a peak in 1981 (Figure 2).

Waste corn remaining in fields after harvest has been a key component of the diets of many wildlife

Authors' address: United States Geological Survey, Northern Prairie Wildlife Research Center, 8711 37th Street SE, Jamestown, ND 58401, USA; e-mail for Krapu: gary_krapu@usgs.gov. 


\section{Wildlife Society Bulletin 2004,32(1):127-136}

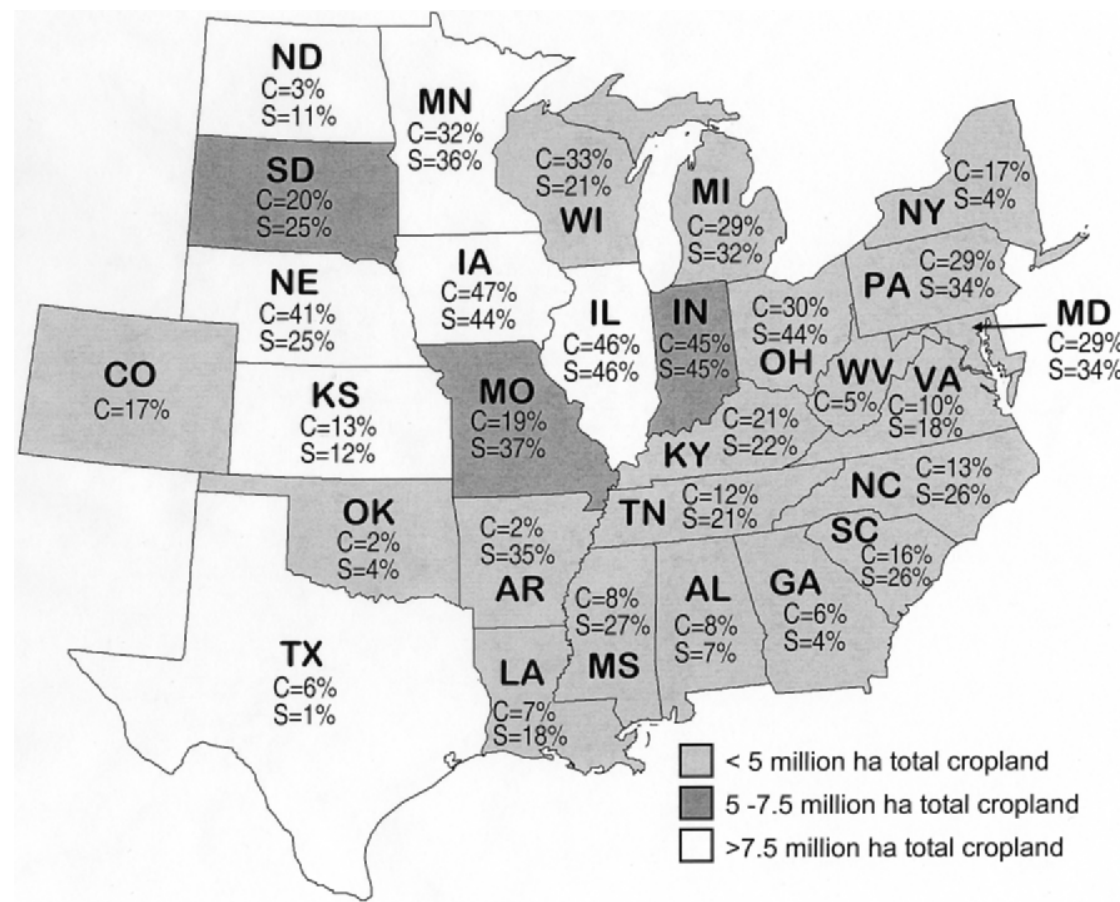

Figure 1. Percentages of harvested cropland in corn (C) and soybeans (S) by state in the United States in 2001. Only states where the combined cropland area in corn and soybeans represented $\geq 5 \%$ of the total cropland area are included. Shading intensity denotes approximate amount of cropland in each state.

species in the United States during fall, winter, and spring (Martin et al. 1951) since at least the 1940s, when mechanical corn pickers came into widespread use in major corn-growing regions (Krapu et al. 1995). An abundance of waste corn (Frederick et al. 1984, Warner et al. 1985) has helped make possible the widespread success of modern wildlife management programs in regions where native habitats no longer were adequate to supply most wildlife nutrient needs. For numerous populations of North

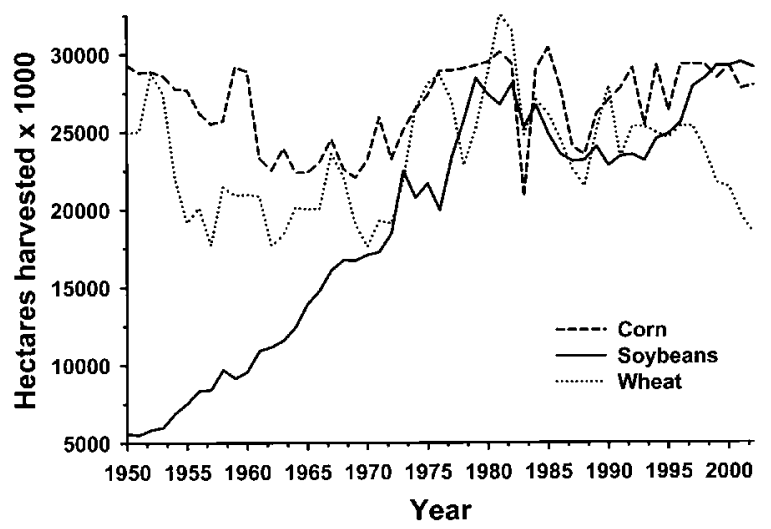

Figure 2. Harvested hectares of corn, soybeans, and wheat in the United States, 1950-2002.
American waterfowl, waste corn became a primary energy source and a precursor for fat synthesis in preparation for migration and reproduction (McLandress and Raveling 1981, Jorde et al. 1983, Alisauskas et al. 1988, Alisauskas and Ankney 1992, Krapu et al. 1995). Waste corn also became a dietary staple for many resident game species including white-tailed deer (Odocoileus virginianus, Sparrowe and Springer 1970), ring-necked pheasants (Phasianus colchicus, Larsen et al. 1994, Bogenschutz et al. 1995), fox squirrels (Sciurus niger, Havera and Smith 1979), wild turkeys (Meleagris gallopavo, Porter 1977), and northern bobwhites (Colinus virginianus,

\section{Newlon et al. 1964).}

In the late 1980s, we observed spring-staging sandhill cranes (Grus canadensis) in the Central Platte River Valley (CPRV) in Nebraska flying farther from their nocturnal roosts on the Platte River to forage than a decade earlier (Krapu et al. 1984). The midcontinent population of sandhill cranes, while in Nebraska, relies on corn residues for most of their energy requirements (Reinecke and Krapu 1986) and for synthesis of fat reserves used during spring migration and reproduction (Krapu et al. 1985). Therefore, we suspected that expansion of foraging areas may reflect, in part, a decline in waste corn on cropland. We had sampled waste corn in the CPRV immediately after harvest during fall 1978 (Reinecke and Krapu 1986), providing a basis for evaluating whether waste corn post-harvest had declined in the CPRV from 1978 and, if so, by how much. We also observed that amount of cropland in the CPRV planted to soybeans had increased sharply from the 1970 s, raising a question of whether soybean intake by cranes and waterfowl had increased. In the late 1970 s, $<1 \%$ of cropland was planted to soybeans (Krapu et al. 1984) and soybeans were not present in esophageal con- 
tents of collected sandhill cranes (Reinecke and Krapu 1986) and white-fronted geese (Krapu et al. 1995). To gain greater insight, we remeasured amount of corn available post-harvest in the CPRV to compare with 1978 and determined extent of soybean consumption by sandhill cranes and 3 of the principal species of Central Flyway waterfowl that stage in the CPRV and adjacent Rainwater Basin Area (RBA) during late winter and early spring.

Specifically, we 1) estimated amount of waste corn present in corn fields in the CPRV, and harvest efficiency during fall 1997 and 1998 and compared with 1978; 2) measured extent of soybean consumption by sandhill cranes, northern pintails (Anas acuta), greater white-fronted geese (Anser albifrons), and lesser snow geese (Chen caerulescens) in the CPRV and adjacent RBA during early spring of 1998 and 1999 , and evaluated adequacy of soybeans in meeting nutritional needs; 3) addressed management implications of findings and ongoing research needs; and 4) identified a possible option for replacing part of the high-energy food resources lost due to changes in production agriculture.

\section{Methods}

We estimated post-harvest corn residues on quarter sections (64.8 ha) randomly selected throughout the CPRV in south-central Nebraska (Reinecke and Krapu 1986). Detailed descriptions of habitats and land use in the CPRV were presented by United States Fish and Wildlife Service (1981), Krapu et al. (1982, 1984), and Sidle et al. (1989). Extent of soybean consumption by spring-staging sandhill cranes, northern pintails, greater white-fronted geese, and lesser snow geese was studied in the CPRV and adjacent RBA. Agricultural land use in the RBA has been described by Krapu et al. (1995).

\section{Corn-harvest efficiency}

We chose 30 quarter sections at random from 180 sections of land in the CPRV in $\mathbf{1 9 7 8}$ for sampling corn residues (Reinecke and Krapu 1986). We obtained permission in 1997 to resample corn residues on 23 of the original 30 quarter sections we surveyed in 1978 . We estimated corn residue (kg/ha) shortly after harvest in November 1997 and 1998 and compared it to results from 1978. In 1978,3 clusters of 3 plots (each $8.29 \times 4.87 \mathrm{~m}$ ) were located randomly within each field, and 1 plot from each cluster was sampled post-harvest
(Frederick et al. 1984). A $2.44 \times 1.68$-m subplot was nested in the corner of each plot; we collected ears of corn from the plot and kernels from the subplot. In 1997-1998, 3-6 clusters of 3 plots were located at random within each field depending on field size, with 1 plot from each cluster sampled and 2 subplots nested in each plot. We based yield estimates for the CPRV on average yields for irrigated corn in Adams, Buffalo, Dawson, Gosper, Hall, Hamilton, Kearney, Merrick, and Phelps counties, which border the portion of the CPRV occupied by sandhill cranes (USDA 1978-2001).

We present waste-corn density measured immediately following harvest during fall. We assessed variation in waste-corn density (kernels, ears, and total) using a mixed-model analysis of variance (PROC MIXED; SAS Institute 1996). We performed a separate analysis for dry mass of each grain type $(\log +1$ transformed), and included year (1978, 1997 , and 1998) as the predictor. We used variation among fields as the error term to test for differences among years.

\section{Soybean consumption by sandbill cranes and waterfowl}

We determined use of soybeans by sandhill cranes, northern pintails, snow geese, and whitefronted geese during springs 1998 and 1999 by collecting birds as they returned to, or after they arrived at, nocturnal roosts in the CPRV and RBA, following foraging on surrounding agricultural lands. We made collections from arrival (February) to departure (late March for waterfowl and early April for sandhill cranes). We froze cranes shortly after collection and later shipped them to a laboratory at the University of Western Ontario, where esophagi were removed and food samples were sorted and checked for presence of soybeans. The esophagi of waterfowl were removed and stored in ethanol, and foods were sorted and checked for presence of soybeans. We included all cranes and waterfowl containing food items in their esophagi in the evaluation of soybean consumption. Sample sizes of birds with food in esophagi by species and year (1998/1999) were as follows: sandhill cranes (82/92); northern pintails (69/70); white-fronted geese (90/108); and snow geese (79/129).

\section{Results and discussion}

\section{Corn-harvest efficiency}

Kernel density did not differ among years $\left(\mathrm{F}_{2,44}\right.$ 
Table 1. Mean corn residues present in the Central Platte River Valley, Nebraska during fall (postharvest) 1978, 1997, and 1998. Values are back-transformed least-squares means in kilograms per hectare. Values in parentheses represent the lower and upper $95 \%$ confidence limits. Means within rows with the same letter do not differ $(P>0.05)$. All comparisons result from mixed-model analyses on transformed $(\log +1)$ data.

\begin{tabular}{lccc}
\hline & \multicolumn{3}{c}{ Year } \\
\cline { 2 - 4 } Corn (kg/ha) & 1978 & 1997 & 1998 \\
\hline Kernels & $79(63,100)$ & $104(79,136)$ & $95(73,124)$ \\
& $\mathrm{A}$ & $\mathrm{A}$ & $\mathrm{A}$ \\
Ears & $230(146,361)$ & $92(55,155)$ & $49(29,82)$ \\
& $\mathrm{A}$ & $\mathrm{B}$ & $\mathrm{B}$ \\
Total waste & $333(261,424)$ & $254(192,335)$ & $177(134,233)$ \\
& $\mathrm{A}$ & $\mathrm{AB}$ & $\mathrm{B}$ \\
\hline
\end{tabular}

$=1.21, P=0.308)$, whereas ear and total waste-corn densities did vary among years (ear, $\mathrm{F}_{2,44}=11.59$, $P<0.0001 ;$ total, $\left.\mathrm{F}_{2,44}=5.64, P=0.007\right)$. In fall 1997 and 1998, post-harvest corn residue averaged 254 and $177 \mathrm{~kg} / \mathrm{ha}$ (Table 1), respectively, or 2.6 and $1.8 \%$ of yield. These levels of waste corn (after rounding) represented 97 and $98 \%$ harvest efficiency in comparison to $96 \%$ in 1978 . In fall 1997 producers farming fields where plots were located indicated that post-harvest corn residues were exceptionally high because a severe storm early in the harvest period caused excessive lodging and breakage of ears from standing stalks. No stormrelated losses of corn were reported in the CPRV during fall 1998. Average yield increased by $20 \%$ from 1978 to 1998 , resulting in post-harvest waste corn in fall 1997 and 1998 averaging 76 and 53\% of 1978. The decline in waste-corn density from 1978 to 1998 resulted from a $79 \%$ reduction in unharvested ears (Table 1), whereas the standing crop of loose corn kernels was similar among years (Table 1). As a result, in 1998 ears accounted for only about $28 \%$ of the waste corn in fields, in contrast to about $69 \%$ in 1978 . The increase in ear retrieval apparently resulted primarily from improvements in combine headers.

A $98.2 \%$ harvest efficiency in 1998, while high, was below the upper limits of corn-harvest efficiency being attained in the United States. Combines in operation for over a decade have produced corn-harvest efficiency rates $\geq 99 \%$ under favorable harvest conditions (Gliem et al. 1990). Reductions of waste corn to $\leq 1 \%$ of the standing crop may not yet be consistently achieved because lodging, combining speed, alignment of combine head width to row width (Hanna et al. 1998), and moisture content of corn (Baldassarre et al. 1983) can affect harvest efficiency. However, with harvest efficiency rates $\geq 99 \%$ currently attainable under some conditions and net profits linked to amount of commodity produced, further increases in cornharvest efficiency are expected. In addition, when cornfields are disced or plowed, $77-97 \%$ of the waste corn can become unavailable to wildlife (Baldassarre and Bolen 1984), drastically reducing wildlife carrying capacity on these lands. In the CPRV and RBA, an estimated 13 and $27 \%$ of the corn ground was fall-tilled during 1997 and 1998, respectively (R. Cox, Jr., Northern Prairie Wildlife Research Center, unpublished data).

\section{Soybean consumption by sandbill cranes and waterfowl}

Soybeans did not occur in esophagi of 174 sandhill cranes that contained food during spring 1998 and 1999, although harvested soybean fields averaged $11 \%$ of cropland area. Soybeans also were absent from the diets of pintails $(n=139)$, whitefronted geese $(n=198)$, and snow geese $(n=208)$ collected in the RBA or CPRV. Lack of soybean consumption by cranes and geese was associated with limited use of soybean fields. From February-April 1998 through $2001,0.1,0,0$, and $2.5 \%$ of quadrant use by Canada geese, snow/Ross' geese (Chen rossii), white-fronted geese, and sandhill cranes, respectively, occurred where $>90 \%$ of agricultural land was in soybeans, whereas $37.5,82.5,53.7$, and $44.9 \%$ of use occurred where $>90 \%$ of the land was in corn (Krapu et al., in press). Low use of soybean

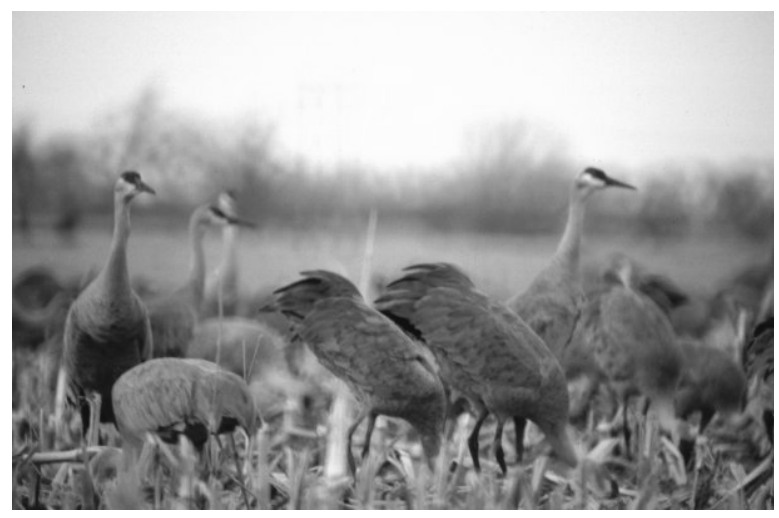

Sandhill cranes feeding on waste corn in the Central Platte River Valley, Nebraska. Waste corn has been a dietary staple of many species of migratory and resident wildlife over the past 60 years, and abundant supplies have contributed greatly to the success of numerous wildlife management programs. 
Table 2. True metabolizable energy (TME) of selected foods fed to Canada geese and mallards and digestibility (DI) for Canada geese.

\begin{tabular}{|c|c|c|c|c|}
\hline \multirow[b]{2}{*}{ Crop } & \multicolumn{2}{|c|}{ Canada goose ${ }^{a}$} & \multicolumn{2}{|c|}{ Mallardb } \\
\hline & TME (kcal/gC) & DI (\%) & TME (kcal/g) & DI (\%) \\
\hline Soybeans & 3.55 & 62.53 & 2.65 & $\mathrm{n} / \mathrm{a}$ \\
\hline Corn & 3.90 & 88.48 & 3.67 & $\mathrm{n} / \mathrm{a}$ \\
\hline Milo & 3.78 & 86.80 & $\mathrm{n} / \mathrm{a}$ & $\mathrm{n} / \mathrm{a}$ \\
\hline Rice & 3.52 & 67.22 & 3.34 & $\mathrm{n} / \mathrm{a}$ \\
\hline Winter wheat & 2.40 & 55.17 & 3.38 & $\mathrm{n} / \mathrm{a}$ \\
\hline
\end{tabular}

a Petrie et al. 1998.

b Reinecke et al. 1989.

C A conversion factor of $1 \mathrm{kcal} / \mathrm{g}=4.184 \mathrm{~kJ} / \mathrm{g}$ (Robbins 1983) was used.

fields by Canada geese in the CPRV occurred despite a true metabolizable energy (TME) value that was average among agricultural foods commonly consumed by Canada geese (Table 2). Absence of soybeans in the diet of studied species and low use of soybean fields by waterfowl while in Nebraska followed a pattern seen among wintering flocks of pintails in Louisiana (Cox and Afton 1997). Relatively low amounts of waste soybeans in fields after harvest (i.e., only about 48 to $63 \mathrm{~kg} / \mathrm{ha}$ [Warner et al. 1985]), or about one-third of the amount of waste corn present in Nebraska cornfields in 1998 (Table 1), may contribute to limited ingestion of soybeans by wildlife (Reinecke et al. 1989). Also, deterioration of soybeans when flooded is 2.3 times faster than for corn, and beans are completely gone after 90 days of flooding (Nelms and Twedt 1996).

Soybeans are consumed by waterfowl under some conditions and, when taken in large quantities, can lead to a deterioration in body condition. In Mississippi, when drought restricts natural feeding opportunities, soybean intake by mallards increases and body masses decline (Delnicki and Reinecke 1986). In North Dakota we examined about 30 wild mallards we had shot after they had field-fed on soybean residues during a 2-week period in late October and early November 1997. Beanfeeding mallards lacked visible fat deposits, in contrast to those we shot feeding on other foods, and fed on beans even though waste corn was also available in the area. Waste beans were conspicuously abundant in the field, which may have increased soybean intake. In experimental feeding trials conducted in Mississippi, captive mallards fed soybeans exclusively from late November to late
February experienced a marked loss in body mass by the end of the 3-month study while those on control, Japanese millet, rice, and corn treatments did not (Loesch and Kaminski 1989). Mallard loss of body mass apparently resulted from a negative energy balance as high serum d-beta-hydroxybutyrate levels indicated lipid catabolism (Dabbert et al. 1996), a result of unprocessed soybeans containing biochemicals that interfere with digestive enzymes and prevent assimilation of nutrients (Reinecke et al. 1989). Bobwhites, like mallards, when fed soybeans exclusively on an ad libitum basis in Kansas lost body mass, in contrast to controls and those fed sorghum (Robel and Arruda 1986). Bobwhites assimilated $45 \%$ of the energy from soybeans as compared to $85 \%$ from sorghum.

Genetically modified (GM) soybeans are replacing conventional soybeans at a rapid rate in the United States. In 2002 an estimated 22.4 million ha of soybeans, $75 \%$ of the soybean crop, was planted to GM types, a 622\% increase since 1997 (Figure 3). The switch to GM soybeans has increased efficacy of weed control as glyphosate herbicides used on GM crops target all plant species except the GM crop. As weed seeds are a major food of many species of game and nongame wildlife (Martin et al. 1951), increased efficacy of weed control on cropland planted to GM soybeans further diminishes the value to wildlife of soybean ground. Before GM crops were developed, herbicides generally were selective, resulting in some weed species continuing to thrive with less competition (Fawcett and Slife 1978), thus partially compensating for the lower nutritional value of soybeans. Recent studies conducted at 12 agricultural experiment stations from

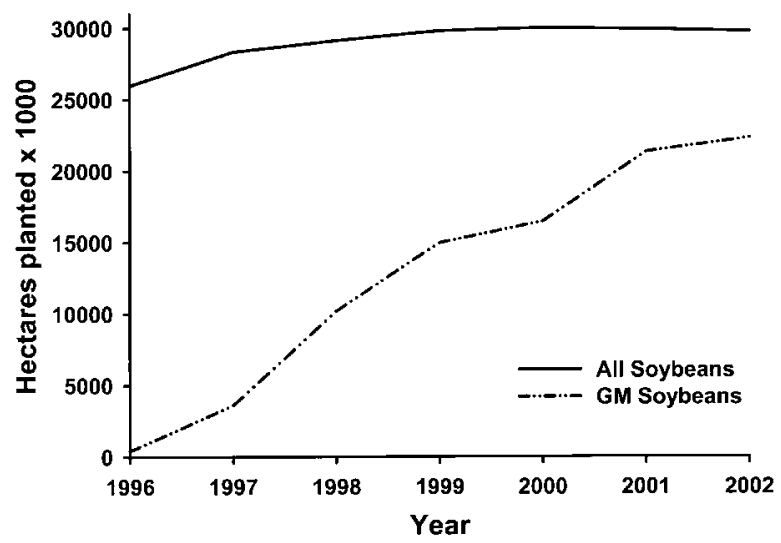

Figure 3. Planted hectares of soybeans (all types) and genetically modified (GM) herbicide-resistant soybeans in the United States, 1996-2002. 
Minnesota to Louisiana indicated that treatment of GM soybeans with glyphosate resulted in increased suppression of dominant weeds when compared to standard herbicide treatments (Peterson et al. 2002). In Great Britain seed rain (amount of weed seed falling to ground surface) was five-fold and three-fold higher for non-GM rape (canola) and sugar beets treated with conventional herbicides than GM varieties treated with glyphosate (Heard et al. 2003).

Genetically modified crops appear poised to dominate agricultural landscapes in the United States, thereby broadening the impact on seed-eating species that rely on high-energy foods and cover produced by weed species. In 2002 an estimated 10.9 million ha (34\%) of the corn crop was planted to GM types (USDA 2002). In Great Britain weed-seed rain was $87 \%$ higher in GM maize (corn) than with conventional control methods (Heard et al. 2003). However, the difference was not detectable in the seed bank because total weed return was low under both treatments, due in part to effectiveness of atrazine, the primary conventional herbicide used to control weeds, and because corn outcompetes all weeds by July. Commercial production of GM wheat in the United States has been stalled to date because the wheat crop is more dependent on export markets than corn and soybeans, and foreign buyers have been reluctant to purchase GM wheat. Potential impacts to wildlife populations from loss of cover and food if GM wheat replaces traditional types likely would be greatest in Colorado, Kansas, Montana, North Dakota, South Dakota, and Washington, where wheat was grown on $33,34,53,43,38$, and $58 \%$, respectively, of harvested cropland in 2001 (USDA 2001).

\section{Management implications}

When harvest efficiency of corn increased from 96\% to $98 \%$ in the CPRV from 1978 to 1998 , fat content of spring-staging greater sandhill cranes (G. $c$. tabida), on average, fell by $46 \%$ (G. Krapu, Northern Prairie Wildlife Research Center, unpublished data). Among white-fronted geese in Nebraska, fat storage rate fell from $14 \mathrm{~g} /$ day in 1978-1979 (Krapu et al. 1995) to 0 g/day in 1998-1999 (R. Cox, Jr., Northern Prairie Wildlife Research Center, unpublished data). As corn accounts for $>90 \%$ of the diet of sandhill cranes (Reinecke and Krapu 1986) and white-fronted geese (Krapu et al. 1995) while stag- ing in Nebraska, reductions in fat storage presumably are linked directly to declining availability of waste corn as combines have become more efficient, cropland area in soybeans has expanded, and competition within and between species for remaining waste corn has increased (Krapu et al. in press). Reduced fat storage by cranes and geese with the decline in corn residues indicates that high-energy food is no longer available on cropland in excess of needs for at least some populations of migratory birds.

Improvements in harvest efficiency and the related decline in post-harvest corn residues over the past 20 years presumably represent a trend that extends nationwide, but similar evaluations are needed from other major corn-growing regions. Wildlife populations are most likely to be affected at current levels of corn-harvest efficiency where large concentrations of wildlife are present for extended periods (e.g., cranes and waterfowl in the CPRV/RBA) and in landscapes where corn yields are relatively low, leaving proportionately less waste corn for wildlife in fields post-harvest. Also, high-energy foods may be inadequate where corn is being replaced by soybeans or other crops having a limited capacity to support wildlife during periods of high-energy demands, or where a high percentage of corn ground is being tilled post-harvest, burying most waste corn. Species vary widely in their mobility and capacity to adapt to declining corn residues. For example, white-tailed deer are less affected as the density of food patches decline than are fox squirrels and ring-necked pheasants, because deer have greater mobility and a lower risk of being predated. Growing efficiency of corn harvest and local replacement of corn by soybeans or other crops less capable of supplying wildlife needs increase the need for wildlife managers to maintain a greater awareness of the status of food resources supporting targeted wildlife populations than was necessary in the past when corn (see Reinecke and Krapu 1986), weed seeds, and other high-energy foods were widely available and present in excess of wildlife needs.

Available information suggests that soybeans are poorly suited for meeting nutritional needs of wildlife during periods when energy requirements are high. This limitation has taken on special significance with cropland area in soybeans now exceeding all other annually planted crops in the United States, and with seeds of weed species on soybean ground severely reduced. The overall 
impact on wildlife populations nationwide from nearly one-quarter of the nation's cropland now being devoted to soybean production, with most in GM types, is unknown. However, based on the marginal capacity of soybeans to meet energy needs of species that have been studied, and with limited alternate food and cover present on soybean ground (including field edges when glyphosate is used), fewer wildlife likely will be supported on soybean ground than when cropland is planted to corn, wheat, and several other crops. Wildlife left without access to adequate high-energy food is likely to store less fat. For mallards, poor condition increases the risk of mortality from hunting (Hepp et al. 1986). These circumstances underscore the importance of maintaining plentiful, widely distributed, high-energy foods for mallards and other seed-eating wildlife populations, particularly in landscapes where soybeans are a major crop.

With passage of The Federal Agriculture Improvement and Reform Act of 1996 (1996 farm bill), producers in the United States were provided a major incentive to expand soybean production. Under the commodity title of the 1996 farm bill, the marketing assistance loan rate for soybeans was set at $\$ 5.26$ per bushel, resulting in a higher net profit (after accounting for cost of production) for soybeans than for corn, wheat, and other commodities (Government Accounting Office 1999). At the $\$ 5.26$ per bushel loan rate for soybeans, the area planted to soybeans in the United States increased by an estimated 4.45 million ha during 1996-2001, even though the market price for soybeans during part of this period was the lowest in 30 years (Wescott and Price 2001). Many wildlife populations likely would benefit if government assistance to soybean producers during periods when target price exceeds market price was set at a level where net profit realized per ha of soybeans did not exceed that of competing crops valuable to wildlife.

\section{Research needs}

How much the recent declines in high-quality foods will affect seed-eating wildlife populations can be expected to vary regionally, depending on species present, population sizes, landscape composition of crops, post-harvest land use, climate, and other factors. However, the potential risk to seedeating game and nongame wildlife populations appears to be enormous should current trends con- tinue and foods capable of satisfying energy needs become scarce on cropland across the United States, emphasizing the need for a comprehensive research effort to study the problem. Little attention is being focused on effect of density and distribution of grain residues or availability of weed seeds and associated cover on condition of seedeating wildlife, their distribution, and capacity to survive and reproduce. Research also is needed to evaluate the extent to which aggressive efforts by county weed boards to eradicate weeds on Conservation Reserve Program (CRP) and other private and public lands affect populations of seed-eating wildlife in an era when high-energy food is declining on cropland. Current knowledge of the ecology of farmland birds has resulted principally from studies conducted during the breeding season, when high-energy foods are less important, emphasizing the need for more research on species' requirements during other seasons (Robinson and Sutherland 2002, Peterjohn 2003).

To date, little attention has been given to the possible effects of GM crops on wildlife populations in the United States, with the exception of the widely publicized evaluation of effects of Bt corn pollen on monarch butterfly (Danaus plexippus) larvae (Brown 2001). The recent rapid expansion of GM crops and associated reduction in high-energy food for wildlife emphasize the need for greater insight into how declines in weed seed and cover on cropland affect the distribution and abundance of species that rely heavily on weeds for their energy needs or cover during part of the annual cycle. Weed-seed banks in cropland have been declining for decades in the United States as new, more efficient weed-control methods have been developed, but few studies have evaluated the significance of this change to seed-eating wildlife populations. In Great Britain, data from Robinson and Sutherland (2002) indicate that declines in weed-seed banks have averaged about 3\% per year since the 1940s, and this change has been accompanied by declines in many seed-eating birds, with losses greatest among those species that forage on seeds in farmland during winter. In North America, several species of seed-eating sparrows, eastern meadowlarks (Sturnella magna), western meadowlarks (S. neglecta), bobolinks (Dolichonyx oryzivorous), lesser goldfinches (Carduelis psaltria), and American goldfinches ( $C$. tristis) have declined sharply since 1966 (Peterjohn et al. 1996), potentially linked in part to a decline in weed seed on 
cropland. In Ohio, red-winged blackbird (Agelaius pboeniceus) population indices decreased by an estimated 53\% during 1966-1996 (Blackwell and Dolbeer 2001). Of 35 crop and climatic variables tested, the highest correlation to changes in blackbird population size was with the combined area of soybeans and corn grown in the state. Cropland area planted to soybeans in Ohio increased by 963,995 ha or $212 \%$ during 1966-1996 (USDA 1966-1996). Overall, grassland birds have declined sharply over the past 2 decades in North America, with population trends strongly linked to changes in agricultural land use (Murphy 2003).

To effectively evaluate possible consequences of declining high-energy food on seed-eating wildlife populations, research should be focused at landscape scales and, where appropriate, take into account cumulative effects on wildlife populations from increased efficacy of weed control, declining residues of crops important to wildlife, and expansion of crops that produce residues of low value to many wildlife species (e.g., soybeans). Detailed information is needed concerning how specific agricultural management practices affect availability of waste grains and weed-seed rain and cumulative effects over time on weed-seed banks on lands consistently planted to GM crops (see Heard et al. 2003). Advances in technology that have made production agriculture in the United States highly efficient also pose risks to wildlife in other nations (see Watkinson et al. 2000, Chamberlain and Vickery 2002, Hails 2002, Robinson and Sutherland 2002). Because wildlife that rely on farmland for food can be expected to face growing shortages worldwide in the decades ahead, greater international cooperation is needed among wildlife researchers, managers, and decision-makers to develop effective strategies to lessen impacts to seed-eating and other wildlife populations as agriculture continues to become more industrialized.

\section{Conservation title of the federal farm bill-part of the solution?}

When our findings are considered in the context of recent agricultural reports published annually by the USDA, they show that most of the nation's cropland is now planted to a few crops with declining capacities to meet wildlife needs, particularly during periods when energy needs of wildlife are high, such as spring and fall migration and during winter. The inclusion of the Conservation Reserve Program in the federal farm program in the mid-1980s rep- resented a key step toward maintaining abundant wildlife in intensively farmed agricultural landscapes (Johnson and Schwartz 1993, Reynolds et al. 2001). However, with production agriculture having become highly efficient and with intensive weed control on CRP and other conservation land, the potential benefits to seed-eating wildlife from scattered tracts of perennial cover, including CRP, will not be realized unless ways can be found to ensure that high-energy foods and associated cover remain widely available (also see Rodgers 1999, 2002). The Conservation Title of the 2002 farm bill potentially could serve as a mechanism for increasing the supply of food for seed-eating wildlife in the United States. Subtitle A-Conservation Security, Sec. $1238 \mathrm{~A}$, includes a provision "to assist producers of agricultural operations in promoting conservation and improvement in the quality of soil, water, air, energy, and plant and animal life, and any other conservation purposes, as determined by the Secretary [of Agriculture]." With appropriate guidelines, producers could be offered incentives to grow high-energy food in plots for wildlife, leave ample residues of crops known to be beneficial to wildlife, use less stringent weed-control methods on cropland, or undertake other measures that would increase amount of high-energy food at sites where it is most needed. How successful natural resource managers are in finding ways to maintain widely distributed, plentiful, and nutritionally suitable foods for seed-eating wildlife populations likely will be a key factor determining levels of wildlife diversity and abundance and the success of many wildlife management programs in the twenty-first century.

Acknowledgments. We thank Region 6 of the United States Fish and Wildlife Service (USFWS); the Rainwater Basin Wetland Management District, USFWS; Ecological Services, USFWS, Grand Island, Nebraska; Nebraska Game and Parks Commission; Rainwater Basin Joint Venture; North American Waterfowl Management Plan; and Platte River Trust for various forms of support during this study.

We are grateful to T. Buhl, J. Drohota, D. Fronczack, R. Griebel, W. Jones, G. Knutsen, A. Olson, F. Sargeant, A. Stonesifer, and R. Woodward for assistance in collecting sandhill cranes and waterfowl for food habits analyses, F. Sargeant for processing waterfowl food samples, and R. Balaban for helping collect post-harvest corn samples in the Central Platte River Valley. We thank W. Newton for assis- 
tance with statistical analyses and K. Van Cleave for obtaining copies of some of the publications cited in this paper. We are grateful to D. Ankney, E. Bollinger, M. Chamberlain, S. Petrie, K. Reinecke, M. Sherfy, and an anonymous reviewer for providing valuable comments on earlier drafts of this manuscript.

\section{Literature cited}

Alisauskas, R. T., AND C. D. Ankney. 1992. Spring habitat use and diets of midcontinent adult lesser snow geese. Journal of Wildlife Management 56:43-54.

Alisauskas, R.T., C. D. ANKNEY, AND E. E. KlaAs. 1988. Winter diets and nutrition of midcontinental lesser snow geese. Journal of Wildlife Management 52:403-414.

BALDASSARRE, G.A.,AND E. G. Bolen. 1984. Field-feeding ecology of waterfowl wintering on the Southern High Plains of Texas. Journal of Wildlife Management 48:63-71.

Baldassarre, G.A., R. J.Whyte, E. E. Quinlan, and E. G. Bolen. 1983. Dynamics and quality of waste corn available to postbreeding waterfowl in Texas. Wildlife Society Bulletin 11:25-31.

Blackwell, B. F., and R. A. DolbeER. 2001. Decline in the redwinged blackbird population in Ohio correlated to changes in agriculture (1965-1996). Journal of Wildlife Management 65:661-667.

Bogenschutz, T. R., D. E. Hubbard, and A. P. Leif. 1995. Corn and sorghum as a winter food for ring-necked pheasants. Journal of Wildlife Management 59:776-784.

BRown, K. 2001. Seeds of concern. Scientific American 284 (4): 52-57.

Chamberlain, D., and J. Vickery. 2002. Declining farmland birds: Evidence from large-scale monitoring studies in the UK. British Birds 95:300-310.

Cox, R. R., JR., AND A. D. AFTon. 1997. Use of habitats by female northern pintails wintering in southwestern Louisiana. Journal of Wildlife Management 61:435-443.

Dabbert, C. B., K. C. Powell, and T. E. Martin. 1996. Effects of monotypic diets of soybeans, rice, and corn on mallard (Anas platyrbynchos) physiological traits. Journal of Zoo and Wildlife Medicine 27:248-254.

Delnicki, D., AND K. J. ReINECKe. 1986. Mid-winter food use and body weights of mallards and wood ducks in Mississippi. Journal of Wildlife Management 50:43-51.

FAWCETT, R. S., AND F.W. SLIFE. 1978. Effects of 2,4-D and dalapon on weed seed production and dormancy. Weed Science 26: 543-547.

Frederick, R. B., E. E. KlaAs, G. A. Baldassarke, and K. J. Reinecke. 1984. A method for sampling waste corn. Journal of Wildlife Management 48: 298-303.

GLIEM, J.A., R. G. Holmes, AND R. K.WoOd. 1990. Corn and soybean harvesting losses. Paper No. 90-1563 at American Society of Agricultural Engineers International Winter Meeting, Chicago, Illinois. Unpublished Report.

Government Accounting Office. 1999. United States Department of Agriculture: Marketing assistance loan program should better reflect market conditions. GAO/RCED00-9. Washington, D.C., USA.

HAILS, R. S. 2002. Assessing the risks associated with new agricultural practices. Nature 418:685-688.

Hanna, H. M., K. D. Kohl, and D. Haden. 1998. Combine losses from narrow and wide row corn harvest. Iowa State Research Farm 00-29.31.

HAVERA, S. P., AND K. E. SMITH. 1979. A nutritional comparison of selected fox squirrel foods. Journal of Wildlife Management 43:691-704.

Heard, M. S., C. Hawes, G. T. Champion, S. J. Clark, L. G. Firbank, A. J. Haughton, A. M. Parish, J. N. Perry, P. Rothery, R. J. Scott, M. P. SKellerN, G. R. SQUiRE, AND M. O. HILl. 2003. Weeds in fields with contrasting conventional and genetically modified herbicide-tolerant crops. I. Effects on abundance and diversity. Philosophical Transactions of The Royal Society of London B. 358: 1819-1832.

Hepp, G. R., R. J. Blohm, R. E. Reynolds, J. E. Hines, AND J. D. Nichols, 1986. Physiological condition of autumn-banded mallards and its relationship to hunting vulnerability. Journal of Wildlife Management 50:177-183.

Johnson, D. H., AND M. D. SChwartz. 1993. The Conservation Reserve Program and grassland birds. Conservation Biology 7:934-937.

Jorde, D. G., G. L. Krapu, ANd R. D. Crawford. 1983. Feeding ecology of mallards wintering in Nebraska. Journal of Wildlife Management 47: 1044-1053.

Krapu, G. L., D. A. Brandt, and R. R. Cox, JR. In Press. Northernnesting geese compete with sandhill cranes for waste corn in the Central Platte Valley, Nebraska. Proceedings of the Ninth North American Crane Workshop.

Krapu, G. L., D. E. Facey, E. K. Fritzell, and D. H. Johnson. 1984. Habitat use by migrant sandhill cranes in Nebraska. Journal of Wildlife Management 48:407-417.

Krapu, G. L., G. C. Iverson, K. J. ReineCKe,And C. M. Boise. 1985. Fat deposition and usage by arctic-nesting sandhill cranes during spring. Auk 102:362-368

Krapu, G. L., K. J. ReIneCKe, AND C. R. Frith. 1982. Sandhill cranes and the Platte River. Transactions of the North American Wildlife and Natural Resources Conference 47:542-552.

Krapu, G. L., K. J. Reinecke, D. G. Jorde, AND S. G. Simpson. 1995. Spring-staging ecology of midcontinent greater white-fronted geese. Journal of Wildlife Management 59:736-746.

Larsen, D. T., P. L. Crookston, AND L. D. Flake. 1994. Factors associated with ring-necked pheasant use of winter food plots. Wildlife Society Bulletin 22:620-626.

LOESCH, C. R., AND R. M. KAMINSKI. 1989. Winter body-weight patterns of female mallards fed agricultural seeds. Journal of Wildlife Management 53:1081-1087.

Martin,A. C., H. S. Zim, and A. L. Nelson. 1951. American wildlife and plants. McGraw-Hill, New York, New York, USA.

MCLANDREss, M. R.,AND D. G. Raveling. 1981. Changes in diet and body composition of Canada geese before spring migration. Auk 98: 65-79.

MurPHY, M.T. 2003. Avian population trends within the evolving agricultural landscape of eastern and central United States. Auk 120:20-34

NeLms, C. O.,AND D. J.TwEDT. 1996. Seed deterioration in flooded agricultural fields during winter. Wildlife Society Bulletin 24: 85-88.

Newlon, C. F., T. S. Baskett, R. P. BReitenbach, and J. A. STANFord. 1964. Sustaining values of emergency foods for bobwhites. Journal of Wildlife Management 28:532-542.

Peterjohn, B. G. 2003. Agricultural landscapes: Can they support healthy bird populations as well as farm products? Auk 120: $14-19$

Peterjohn, B. G., J. R. Sauer, and W. A. Link. 1996. The 1994 and 1995 summary of the North American breeding bird survey. 
Bird Populations 3:48-66.

Peterson, D., J. Scursoni, and F. Forcella. 2002. Weed diversity and yield in glyphosate-tolerant soybean from Minnesota to Louisiana. North Central Weed Science Society Abstracts 57: 129.

Petrie, M. J., R. D. Drobney, And D. A. Graber. 1998. True metabolizable energy estimates of Canada goose foods. Journal of Wildlife Management 62:1147-1152.

PORTER, W. F. 1977. Utilization of agricultural habitats by wild turkeys in southeastern Minnesota. International Congress of Game Biologists 13:319-323.

ReineCKe, K. J., R. M. Kaminski, D. J. Moorhead, J. D. Hodges, and J. R. Nassar. 1989. Mississippi Alluvial Valley. Pages 203-247 in L. M. Smith, R. L. Pederson, and R. M. Kaminski, editors, Habitat management for migrating and wintering waterfowl in North America. Texas Tech University Press, Lubbock, USA.

ReineCKe, K. J., AND G. L. KraPu. 1986. Feeding ecology of sandhill cranes during spring migration in Nebraska. Journal of Wildlife Management 50:71-79.

REYNOLDS, R. E., T. L. SHAFFer, R. W. RENNER, W. E. NEWTON, AND B. D. J. BATT. 2001. Impact of the Conservation Reserve Program on duck recruitment in the U.S. Prairie Pothole Region. Journal of Wildlife Management 65:765-780.

RobBins, C. T. 1983. Wildlife feeding and nutrition. Academic Press, Orlando, Florida, USA

Robel, R. J., AND S. M. ARrudA. 1986. Energetics and weight changes of northern bobwhites fed 6 different foods. Journal of Wildlife Management 50:236-238.

Robinson, R.A., AND W. J. Sutherland. 2002. Post-war changes in arable farming and biodiversity in Great Britain. Journal of Applied Ecology 39: 157-176.

RODGERS, R. D. 1999. Why haven't pheasant populations in western Kansas increased with CRP? Wildlife Society Bulletin 27: 654-665.

RODGERs, R. D. 2002. Effects of wheat-stubble height and weed control on winter pheasant abundance. Wildlife Society Bulletin 30: 1099-1112.

SAS INSTITUTE. 1996. SAS/STAT software: changes and enhancements through release 6.11. SAS Institute, Cary, North Carolina, USA.

SidLE, J. G., E. D. Miller, AND P. J. CuRRIER. 1989. Changing habitats in the Platte River Valley of Nebraska. Prairie Naturalist 21: 91-104.

SPARROWE, R. D.,AND P. F. SPRINGER. 1970. Seasonal activity patterns of white-tailed deer in eastern South Dakota. Journal of Wildlife Management 34:420-431.

United States Department of Agriculture. 1950-2002. Agricultural statistics. National Agricultural Statistics Research Service, Washington, D.C., USA.

United States Fish and Wild iffe Service. 1981. The Platte River Ecology Study. United States Fish and Wildlife Service Special Research Report, Jamestown, North Dakota, USA.

Warner, R. E., S. P. Havera, and L. M. David. 1985. Effects of autumn tillage systems on corn and soybean harvest residues in Illinois. Journal of Wildlife Management 49: 185-190.
Watkinson, A. R., R. P. Freckleton, R. A. Robinson, and W. J. SutherLAND. 2000. Predictions of biodiversity response to genetically modified herbicide-tolerant crops. Science 289 : 1554-1557.

Westcott, P. C., and J. M. Price. 2001. Analysis of the U.S. commodity loan program with marketing loan provisions. Market and Trade Economics Division, Economic Research Service, United States Department of Agriculture, Agricultural Economic Report No. 801.

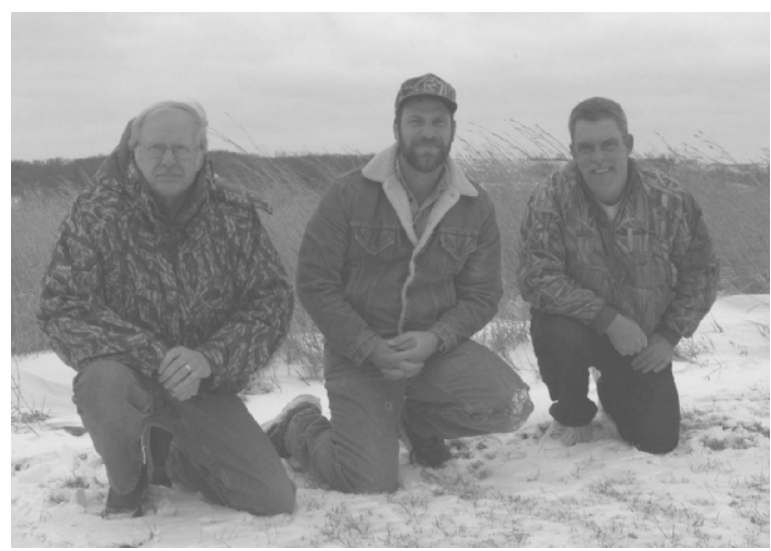

Gary L. Krapu (left) is a research wildlife biologist with the United States Geological Survey (USGS) at the Northern Prairie Wildlife Research Center at Jamestown, North Dakota. He obtained his B.S. (1966) in zoology from North Dakota State University and M.S. (1968) and Ph.D. (1972) in animal ecology at lowa State University. His research focuses primarily on ecological and physiological requirements of midcontinent populations of waterfowl and sandhill cranes. He is Vice-President of the North American Crane Working Group. David A. (Dave) Brandt (center) is a wildlife biologist with the USGS at the Northern Prairie Wildlife Research Center. He earned his B.S. (1988) from lowa State University in fisheries and wildlife biology. His areas of interest include breeding biology of waterfowl in the northern Great Plains, ecology and management of sandhill cranes, and new developments in technologies and techniques used in wildlife research. Robert $\boldsymbol{R}$. (Bobby) Cox, Jr. (right) is a research wildlife biologist with the USGS at Northern Prairie Wildlife Research Center. He earned his B.S. (1986) in forest resources (wildlife concentration) at the University of Georgia, his M.S. (1993) in fisheries and wildlife from Utah State University, and his Ph.D. (1996) in wildlife and fisheries science from Louisiana State University. His research interests include all aspects of waterfowl ecology and management.

Associate editor: Chamberlain 